\title{
Short Communication: Composition of Milk Protein and Milk Fatty Acids Is Stable for Cows Differing in Genetic Merit for Milk Production'
}

\author{
G. Bobe, ${ }^{\star 2}$ G. L. Lindberg, ${ }^{*}$ A. E. Freeman, $\nmid$ and D. C. Beitz ${ }^{\star 3}$ \\ *Nutritional Physiology Group, and \\ †Animal Breeding and Genetic Group, Department of Animal Science, lowa State University, Ames 50011
}

\begin{abstract}
Changing the composition of milk protein and of milk fatty acids alters nutritional and physical properties of dairy products and their consumer appeal. Genetic selection for milk yield decreases concentrations of milk protein and of milk fat. Little is known, however, about how the decrease affects composition of milk protein and milk fatty acids. The objective of this study was to quantify changes in composition of milk protein and of milk fatty acids in cows differing in genetic merit for milk production. Three measures of genetic merit for milk production were used for each cow: genetic line, parent average predicted transmitting ability (PTA) for milk, and cow milk PTA. Composition of milk protein and milk fatty acids were compared in 448 milk samples from 178 cows representing 2 divergent lines of Holsteins that were bred for high or average PTA for milk and combined milk protein and fat yield. High-line cows $(\mathrm{n}=97)$ produced more milk that contained less fat and had higher proportions of $\alpha_{\mathrm{S} 1}$-casein in milk protein than did average-line cows $(n=81)$. We additionally obtained from 233 cows (178 cows representing the 2 genetic lines and 55 cows with ancestors from both genetic lines) the parent average milk PTA and cow milk PTA and compared composition of milk protein and of milk fatty acids in 592 milk samples. Cows whose parent average milk PTA was above or equal to the median of the 233 cows produced more milk that contained less protein and less fat and that tended to have greater proportions of $\alpha_{\mathrm{S1}}$-casein in milk protein than cows whose average milk PTA was below the median. Similarly, cows with above or equal median milk PTA of the 233 cows produced more milk that contained less protein and less fat and had greater proportions of $\alpha_{\mathrm{S1}^{-}}$
\end{abstract}

Received February 8, 2007.

Accepted April 12, 2007.

${ }^{1}$ Publication of the Iowa Agriculture and Home Economics Experiment Station, Ames, project number 3801.

${ }^{2}$ Present address: Division of Cancer Prevention, National Cancer Institute, National Institutes of Health, Frederick, MD 21702.

${ }^{3}$ Corresponding author: dcbeitz@iastate.edu casein in milk protein than did cows with below-median milk PTA. Milk fatty acid composition was not consistently different between groups. Therefore, selection for milk yield decreased concentrations of milk protein and milk fat but had little effect on composition of milk protein and milk fatty acids.

Key words: dairy cow, fatty acid composition, protein composition, selection

\section{INTRODUCTION}

Composition of milk protein and of milk fatty acids recently has gained interest from manufacturers and consumers, because it influences nutritional, physical, and flavor properties of dairy products and consumer acceptance of dairy products. Small to moderate heritabilities of milk protein composition (Renner and Kosmack, 1975; Kroeker et al., 1985; Bobe et al., 1999b) and of milk fatty acid composition (Renner and Kosmack, 1974a; Karijord et al., 1982; Edwards et al., 1973) as well as breed differences in milk protein profiles (Rolleri et al., 1956; McLean et al., 1984) and in milk fatty acid profiles (DePeters et al., 1995; Kelsey et al., 2003; Auldist et al., 2004; Soyeurt et al., 2006) suggest that genetic selection for milk production might affect composition of milk protein and of milk fatty acids.

Over the last half-century, most dairy breeding programs have been based on selection for increased milk production and fat content, which increases milk yield and improves production efficiency of dairy cows. As predicted, genetic selection for increased milk production resulted in decreased fat and, to a smaller extent, in decreased protein in milk in the US Holstein population (Wilcox et al., 1971; Kelm et al., 2000). Effects on milk protein composition have not been tested, and effects on milk fatty acid composition have been reported only for a limited number of cows ( $=22$; Kay et al., 2005). Therefore, the objective of this study was to examine whether selection for milk production alters composition of milk protein and of milk fatty acids of Holstein cows. 


\section{MATERIALS AND METHODS}

\section{Experimental Design and Sample Collection}

For 1 yr (August 1993 to July 1994), milk samples were collected once a month from Holstein-Friesian cows at the Iowa State University Dairy Breeding Research Facility (Ankeny). A subset of 592 individual samples from 233 cows was selected for chemical analysis in 2 stages (Bobe et al., 1999b). First, one-third of the milk samples were chosen randomly for analysis. To obtain, if possible, at least 2 milk samples from each cow for analysis, 1 or 2 milk samples were additionally chosen randomly from cows that had less than 2 milk samples selected in the first stage. From the 233 cows, 26 cows were sampled once, 109 cows 2 times, 59 cows 3 times, 27 cows 4 times, 9 cows 5 times, and 3 cows 6 times. The sampled herd is representative of the US Holstein-Friesian population and is comprised of 2 genetic lines (Dunklee et al., 1994). During 1968, 43 pairs of open heifers were purchased (1 heifer with high milk PTA and the other with low milk PTA). Cows with high milk PTA were bred to sires with the highest milk PTA, and cows with low milk PTA were bred to sires with average milk PTA in the US AI population. Female offspring from these matings were bred over the following $19 \mathrm{yr}$ to sires from the same milk PTA line. Cows were bred in the next $7 \mathrm{yr}$ to sires selected for high or average combined milk protein and fat production PTA. Sires were used for matings for 2 consecutive years, and new sires were added each year. Voluntary culling was based on low milk production, expressed as difference from herdmates within genetic lines, and was used to keep numbers of milking cows nearly equal for the 2 lines (Dunklee et al., 1994). On average, cows had been selected for 4 to 5 generations for milk PTA and for 1 generation for combined milk protein and fat yield PTA.

Cows were classified for genetic merit for milk production in 3 ways: genetic line, parent average milk PTA, and cow milk PTA. For comparison of the genetic lines, only 178 cows whose ancestors remained in the same milk and combined milk protein and fat production PTA line were used. The other 55 cows were from pedigrees in which ancestors were within the herd but from the high milk PTA line and the average milk protein and fat yield PTA line or from the average milk PTA line and the high milk protein and fat yield PTA line. In addition, the milk PTA of all 233 cows and their respective sires and dams were obtained for June 1997 from the USDA Animal Improvement Programs Laboratory. Based on the median parent average milk PTA of the 233 cows $(51.3 \mathrm{~kg})$, cows were grouped as having above or equal $(\mathrm{n}=117)$ vs. below-median parent milk PTA $(n=116)$. Based on the median milk PTA of the
Table 1. Nutrient composition of cow diets

\begin{tabular}{lccr}
\hline & \multicolumn{3}{c}{ Stage of lacation $^{1}$} \\
\cline { 2 - 4 } Chemical & Early & Medium & Late \\
\cline { 2 - 4 } & & $(\mathrm{g} / 100 \text { g of DM })^{2}$ & \\
DM (\% of diet) & 59.0 & 57.5 & 48.0 \\
$\mathrm{CP}$ & 15.56 & 14.67 & 12.38 \\
$\mathrm{RUP}$ & 5.81 & 5.11 & 3.98 \\
$\mathrm{Crude}$ fat & 4.29 & 1.32 & 0.05 \\
$\mathrm{NE}$ (Mcal/kg) & 1.76 & 1.72 & 1.59 \\
$\mathrm{NDF}$ & 30.87 & 29.79 & 34.93 \\
$\mathrm{ADF}$ & 20.50 & 19.01 & 22.82 \\
$\mathrm{NFC}$ & 41.69 & 0.66 & 48.98 \\
$\mathrm{Ca}$ & 0.84 & 0.45 & 0.62 \\
$\mathrm{P}$ & 0.61 & 0.33 & 0.27 \\
$\mathrm{Mg}$ & 0.25 & 0.20 & 0.25 \\
$\mathrm{Na}$ & 0.12 & 2.84 & 0.06 \\
$\mathrm{~K}$ & 0.90 & 0.26 & 1.75 \\
$\mathrm{Cl}$ & 0.25 & 0.21 & 0.13 \\
$\mathrm{~S}$ & 0.15 & 0.12 \\
\hline
\end{tabular}

${ }^{1}$ The diets were calculated to meet the nutrition requirements for a $637-\mathrm{kg}$ cow that produces $41 \mathrm{~kg} / \mathrm{d}$ of milk with $3.4 \%$ fat and $3.0 \%$ protein and gains $0.36 \mathrm{~kg} / \mathrm{d}$ of weight (early), for a $612-\mathrm{kg}$ cow that produces $36 \mathrm{~kg} / \mathrm{d}$ of milk with $3.4 \%$ fat and $2.9 \%$ protein and gains $0.45 \mathrm{~kg} / \mathrm{d}$ of weight (medium), and for a $612-\mathrm{kg}$ cow that produces 18 $\mathrm{kg} / \mathrm{d}$ of milk with $3.4 \%$ fat and $2.9 \%$ protein and gains $0.45 \mathrm{~kg} / \mathrm{d}$ of weight (late).

${ }^{2}$ Units of measure of all variables except where noted.

${ }^{3} \mathrm{NFC}=100-(\% \mathrm{NDF}+\% \mathrm{CP}+\%$ ether extract $+\%$ ash $)$.

233 cows $(62.1 \mathrm{~kg})$, cows were grouped as having above or equal $(\mathrm{n}=117)$ vs. below-median cow milk PTA $(n=116)$.

Cows were housed in a free-stall barn and were fed a fresh TMR twice daily for ad libitum intake with continuous access to feed except during twice-daily milkings $12 \mathrm{~h}$ apart. Refused feed was removed before the evening feeding. Cows were fed 1 of 3 rations (Table 1), which consisted primarily of corn silage, alfalfa hay, soybean meal, and a grain mix. Rations were formulated by using the Spartan Dairy Ration Balancer (Michigan State University, East Lansing) to meet nutrient requirements of lactating cows at different milk production levels according to the NRC (2001). Cows were managed and treated in accordance with guidelines established by the Iowa State University Committee on Animal Care.

\section{Chemical Analyses}

Milk samples were collected from 2 successive milkings and were sent refrigerated to Swiss Valley Farms (Davenport, IA) to be analyzed for total fat and for total protein by midinfrared spectrophotometry (Milk-OScan 203, Foss Food Technology Corp., Eden Prairie, MN) and for SCC by using a Fossomatic 90 (Foss Food Technology Corp.). Protein content was based on total N content and did not exclude NPN. Relative amounts 
of milk proteins and the $\kappa$-CN and $\beta$-LG phenotypes of individual cows were determined from the milk samples by reversed-phase HPLC (Bobe et al., 1998). Milk fatty acids were transesterified to butyl esters, and relative amounts of 27 different fatty acids from C4:0 to C20:1 were quantified by gas chromatography on a $30-\mathrm{m}$ SP2380 fused-silica capillary column with a $0.25-\mathrm{mm}$ i.d. and $0.2-\mu \mathrm{m}$ film thickness (Supelco, Bellefonte, PA) in a Hewlett-Packard (Palo Alto, CA) 5830A gas chromatograph that was connected to a Hewlett-Packard 18859A gas chromatograph terminal (Bobe et al., 1999a). The carrier gas was He at $3 \mathrm{~mL} / \mathrm{min}$. The injector and detector were maintained at $250^{\circ} \mathrm{C}$, and the oven was programmed from $70^{\circ} \mathrm{C}$, after $3 \mathrm{~min}$, to $215^{\circ} \mathrm{C}$ at $4.5^{\circ} \mathrm{C} /$ min and held at $215^{\circ} \mathrm{C}$ for $15 \mathrm{~min}$. An internal standard that contained $\mathrm{C} 13: 0$ was added for quantification of C4:0 to C20:1. External standards (GLC73 and GLC79; Nu-Chek Prep, Elysian, MN) were used to verify the accuracy of the analyses. Results are reported for the 11 of the 27 identified fatty acids that individually accounted for over $1 \%$ of the weight of total fatty acids and that together accounted for $94.9 \%$ of the weight of total fatty acids.

\section{Statistical Analyses}

Statistical analysis was done by using the mixed models procedure (PROC MIXED) of SAS Version 9.1.3 (SAS, 2002). Three estimates of genetic merit for milk production were used: genetic line, parent average milk PTA, and cow milk PTA. Differences between genetic lines, differences between parent average milk PTA groups, and differences between cow milk PTA groups were calculated in separate statistical models using the model equation:

$$
\begin{aligned}
\mathrm{Y}_{\mathrm{ijklmnopqr}}= & \mathrm{PTA}_{\mathrm{i}}+\text { Parity }_{\mathrm{j}}+\mathrm{LM}_{\mathrm{k}}+\mathrm{SM}_{\mathrm{l}}+\operatorname{Diet}_{\mathrm{m}}+\mathrm{SCCG}_{\mathrm{n}} \\
& +\mathrm{KCN}_{\mathrm{o}}+\mathrm{BLG}_{\mathrm{p}}+\mathrm{cow}_{\mathrm{q}}+\mathrm{e}_{\mathrm{r}}
\end{aligned}
$$

where $Y_{\text {ijklmnopqr }}=$ vector of 592 daily milk records (e.g., milk yield, milk protein yield, and milk fat yield expressed in $\mathrm{g} / \mathrm{d}$; milk protein and milk fat content expressed in $\mathrm{g} / \mathrm{L}$; and composition of milk protein expressed as weight percentage of an individual milk protein to total milk protein and composition of milk fatty acids expressed as weight percentage of an individual milk fatty acid to total milk fatty acids). The independent variables were distributed normally; $\mathrm{PTA}_{\mathrm{i}}=$ fixed genetic PTA line (high, average), parent average milk PTA group (above or equal, below median), or cow milk PTA group (above or equal, below median) effect; Parity $_{\mathrm{j}}=$ fixed parity effect $(1,2,3$, and $>3$ parities); $\mathrm{LM}_{\mathrm{k}}=$ fixed lactation month effect (1, 2, ..., 10 and >10 lactation month); $\mathrm{SM}_{1}=$ fixed sampling month effect (January, February, May, June, July,..., December); Diet $_{m}=$ fixed diet effect (early, medium, and late lactation); $\mathrm{SCCG}_{\mathrm{n}}=$ fixed severity of mastitis group effect $(<250,000,250,000$ to $1,000,000$, and $>1,000,000$ cells $/ \mathrm{mL}$ SCC); $\mathrm{KCN}_{0}=$ fixed $\kappa-\mathrm{CN}$ phenotype effect (AA, AB, and BB); $\mathrm{BLG}_{\mathrm{p}}=$ fixed $\beta-\mathrm{LG}$ phenotype effect $(\mathrm{AA}, \mathrm{AB}$, and $\mathrm{BB}) ; \operatorname{cow}_{\mathrm{q}}=$ random cow effect (233 cows). A first-order autoregressive variance-covariance structure (equal variances and covariances being the variances times the repeated-measures correlation coefficient raised to increasing power of the correlation coefficient as the measures become further separated by time) was used to account for repeated measures taken on individual cows across time; $\mathrm{e}_{\mathrm{r}}=$ random residual effect.

Differences and standard errors of differences between genetic lines, between parent average milk PTA groups, and between cow milk PTA groups presented in the text were determined using separate statistical models with a 2 -sided $t$-test (ESTIMATE statement in SAS). To test whether genetic selection for milk production affects the milk fatty acid profile differentially depending on the month of lactation, the interaction term for genetic merit for milk production by month of lactation $\left(\mathrm{PTA}_{\mathrm{i}} \times \mathrm{LM}_{\mathrm{k}}\right)$ was included additionally in the statistical model. For each lactation month, effects of genetic lines, parent average milk PTA groups, and cow milk PTA groups were determined separately with 2sided $t$-tests from the interaction term for genetic merit for milk production by month of lactation. Significance was declared at $P \leq 0.05$, and trends toward significance were declared at $P \leq 0.10$. Means and standard errors of the means presented in tables are least squares means and the larger standard errors of the means of the 2 groups.

\section{RESULTS AND DISCUSSION}

Selection for milk PTA increased milk yield (Table 2). Milk production was $2.34 \pm 0.81 \mathrm{~kg} / \mathrm{d}\{[(25.85-23.34) /$ $23.34] \times 100 \%=9.9 \%$ greater in the high compared with the average line ( $P=0.004$; Table 2$)$. These differences are smaller than the 16.4 and $12.5 \%$ previously reported for the Iowa State University breeding herd (Bertrand et al., 1985; Dunklee et al., 1994) and for other similar breeding programs as reviewed by Kelm et al. (2000). To compare cows with larger differences in milk yield, we additionally obtained the milk PTA of the cows and their parents and grouped them according to the parent average milk PTA or the cow milk PTA into above or equal or below-median PTA. Cows whose parent average milk PTA was above or equal the median produced $2.32 \pm 0.70 \mathrm{~kg} / \mathrm{d}(9.7 \%)$ more milk than did cows with below-median parent average PTA 
Table 2. Least squares means and significance of differences in milk protein profile of cows differing in genetic merit for milk production

\begin{tabular}{|c|c|c|c|c|c|c|c|c|c|c|c|c|}
\hline \multirow[b]{2}{*}{ Milk variable } & \multicolumn{4}{|c|}{$\begin{array}{l}\text { Cows selected for high or } \\
\text { average milk and combined milk } \\
\text { protein and fat production PTA }\end{array}$} & \multicolumn{4}{|c|}{$\begin{array}{l}\text { Cows whose parents had above } \\
\text { or equal or below-median } \\
\text { milk production PTA }\end{array}$} & \multicolumn{4}{|c|}{$\begin{array}{l}\text { Cows with above or } \\
\text { equal or below-median milk } \\
\text { production PTA }\end{array}$} \\
\hline & $\begin{array}{c}\text { High } \\
(\mathrm{C}=98)^{1} \\
(\mathrm{n}=249)\end{array}$ & $\begin{array}{l}\text { Average } \\
(\mathrm{C}=80) \\
(\mathrm{n}=199)\end{array}$ & SEM & $P$-value & $\begin{array}{c}\text { Above } \\
(\mathrm{C}=117) \\
(\mathrm{n}=302)\end{array}$ & $\begin{array}{c}\text { Below } \\
(\mathrm{C}=116) \\
(\mathrm{n}=290)\end{array}$ & SEM & $P$-value & $\begin{array}{c}\text { Above } \\
(\mathrm{C}=117) \\
(\mathrm{n}=304)\end{array}$ & $\begin{array}{c}\text { Below } \\
(\mathrm{C}=116) \\
(\mathrm{n}=288)\end{array}$ & SEM & $P$-value \\
\hline \multicolumn{13}{|l|}{ Amount $(\mathrm{g} / \mathrm{d})^{2}$} \\
\hline Milk (kg/d) & 25.86 & 23.52 & 0.93 & $<0.01$ & 26.22 & 23.91 & 0.88 & $<0.01$ & 28.00 & 22.90 & 0.83 & $<0.01$ \\
\hline \multicolumn{13}{|c|}{ Concentration $(\mathrm{g} / \mathrm{L})$} \\
\hline Protein & 32.46 & 32.99 & 0.38 & 0.11 & 32.25 & 33.02 & 0.37 & $<0.01$ & 32.08 & 33.10 & 0.37 & $<0.01$ \\
\hline Fat & 32.94 & 34.88 & 0.93 & 0.02 & 32.46 & 34.72 & 0.88 & $<0.01$ & 32.08 & 34.89 & 0.89 & $<0.01$ \\
\hline \multicolumn{13}{|c|}{ Proportion of total protein (wt \%) } \\
\hline Casein & 85.92 & 85.81 & 0.26 & 0.60 & 86.01 & 85.74 & 0.25 & 0.18 & 85.87 & 85.84 & 0.26 & 0.88 \\
\hline$\alpha$-LA & 3.74 & 3.71 & 0.09 & 0.65 & 3.75 & 3.74 & 0.08 & 0.86 & 3.77 & 3.72 & 0.08 & 0.42 \\
\hline$\beta$-LG & 10.43 & 10.48 & 0.21 & 0.80 & 10.37 & 10.53 & 0.21 & 0.32 & 10.48 & 10.46 & 0.21 & 0.88 \\
\hline
\end{tabular}

${ }^{1} \mathrm{C}=$ number of cows; 178 cows with ancestors from 1 genetic line and 55 cows with ancestors within the herd from both genetic lines.

${ }^{2}$ Units of measure of all variables except where noted.

$(P=0.001)$. Cows whose milk PTA was above or equal the median produced $5.08 \pm 0.67 \mathrm{~kg} / \mathrm{d}(22.2 \%)$ more milk than did cows with below-median milk PTA $(P<0.0001$; Table 2).

Consistent with previous reports for this herd (Dunklee et al., 1994) and in general (Kelm et al., 2000), selection for milk PTA decreased concentrations of milk components, with a stronger effect on total fat than on protein (Table 2). Concentrations of milk protein and of milk fat were or tended to be lower in cows with higher genetic merit for milk production in all 3 comparisons (Table 2). Differences in milk fat content between groups were more than twice as large as were differences in milk protein content (Table 2), which could explain why herd averages for milk fat content were lower than and milk protein content were similar to breed averages for milk fat and for milk protein content, respectively. Milk protein yield and milk fat yield were greater in cows with higher genetic merit for milk production; however, the differences in fat yield were significant only between cows differing in milk PTA (Table 2).

Selection for milk PTA had little effect on milk protein composition (Table 2). The only difference observed in all 3 comparisons was a greater proportion of $\alpha_{\mathrm{S} 1}$ CN in milk protein of cows with higher genetic merit for milk production (Table 2). Cows of the high selection line had greater proportions of $\alpha_{\mathrm{S} 1}-\mathrm{CN}(0.39 \pm 0.18 \%)$ than did cows of the average selection line $(P=0.03)$. Cows whose parent average milk PTA was above or equal the median tended to have greater proportions of $\alpha_{\mathrm{S} 1}-\mathrm{CN}(0.28 \pm 0.15 \%)$ than did cows with belowmedian parent average milk PTA $(P=0.07)$, and cows whose parent average milk PTA was above or equal the median had greater proportions of $\alpha_{\mathrm{S} 1}-\mathrm{CN}(0.38 \pm$ $0.16 \%)$ than did cows with below-median milk PTA $(P=$ $0.02)$. The differences in $\alpha_{\mathrm{S} 1}$-CN proportions between the groups, however, were small and thus of minor nutritional or economic significance. The effect of selection for milk yield on milk protein composition has not been reported previously. In agreement with our results, Gernand (1988) reported no significant genetic correlations between milk yield and milk protein composition. Differences in milk protein composition among breeds have been reported (Rolleri et al., 1956; McLean et al., 1984) and can be attributed to differences in major milk protein phenotypes, which are known to strongly affect milk protein composition but not milk yield (Jakob, 1994; Bobe et al., 1999b; Ng-Kwai-Hang and Grosclaude, 2003). Effects of $\alpha_{\mathrm{S} 1}-\mathrm{CN}$ genotypes on milk yield have been reported; however, the frequency of those genotypes in the cow population was low, and the effects on milk yield were not consistent (Lien et al., 1995; Prinzenberg et al., 2003; Kuss et al., 2005; Sanders et al., 2006). Therefore, it is unlikely that selection for milk yield alters milk protein composition.

Consistent with results of a small study $(n=22$; Kay et al., 2005), selection for milk yield did not affect milk fatty acid composition (Table 3). These results were surprising, given that breeds differ in milk fatty acid 
Table 3. Least squares means and significance of differences in milk fatty acid profile of cows differing in genetic merit for milk production

\begin{tabular}{|c|c|c|c|c|c|c|c|c|c|c|c|c|}
\hline \multirow[b]{2}{*}{ Milk fatty acids } & \multicolumn{4}{|c|}{$\begin{array}{l}\text { Cows selected for high or } \\
\text { average milk and combined milk } \\
\text { protein and fat production PTA }\end{array}$} & \multicolumn{4}{|c|}{$\begin{array}{l}\text { Cows whose parents had above } \\
\text { or equal or below-median } \\
\text { milk production PTA }\end{array}$} & \multicolumn{4}{|c|}{$\begin{array}{l}\text { Cows with above or } \\
\text { equal or below-median milk } \\
\text { production PTA }\end{array}$} \\
\hline & $\begin{array}{c}\text { High } \\
(\mathrm{C}=98)^{1} \\
(\mathrm{n}=249)\end{array}$ & $\begin{array}{l}\text { Average } \\
(\mathrm{C}=80) \\
(\mathrm{n}=199)\end{array}$ & SEM & $P$-value & $\begin{array}{c}\text { Above } \\
(\mathrm{C}=117) \\
(\mathrm{n}=302)\end{array}$ & $\begin{array}{l}\text { Below } \\
(\mathrm{C}=116) \\
(\mathrm{n}=290)\end{array}$ & SEM & $P$-value & $\begin{array}{l}\text { Above } \\
(\mathrm{C}=117) \\
(\mathrm{n}=304)\end{array}$ & $\begin{array}{l}\text { Below } \\
(\mathrm{C}=116) \\
(\mathrm{n}=288)\end{array}$ & SEM & $P$-value \\
\hline \multicolumn{13}{|c|}{ Proportion of total fatty acids (wt \%) } \\
\hline Saturated & 67.11 & 67.16 & 0.50 & 0.91 & 67.15 & 67.24 & 0.48 & 0.81 & 67.17 & 67.24 & 0.49 & 0.86 \\
\hline $\mathrm{C} 4: 0$ & 3.96 & 3.79 & 0.10 & 0.05 & 3.90 & 3.80 & 0.10 & 0.18 & 3.91 & 3.80 & 0.10 & 0.16 \\
\hline C6:0 & 2.02 & 1.95 & 0.05 & 0.07 & 1.99 & 1.98 & 0.04 & 0.63 & 2.00 & 1.97 & 0.05 & 0.41 \\
\hline C8:0 & 1.14 & 1.11 & 0.03 & 0.18 & 1.13 & 1.13 & 0.03 & 1.00 & 1.13 & 1.13 & 0.03 & 0.96 \\
\hline C10:0 & 2.72 & 2.66 & 0.08 & 0.37 & 2.72 & 2.70 & 0.07 & 0.82 & 2.70 & 2.71 & 0.07 & 0.86 \\
\hline C12:0 & 2.96 & 2.93 & 0.09 & 0.68 & 2.96 & 2.96 & 0.08 & 0.94 & 2.93 & 2.97 & 0.08 & 0.52 \\
\hline C14:0 & 10.55 & 10.45 & 0.17 & 0.49 & 10.61 & 10.48 & 0.16 & 0.29 & 10.60 & 10.50 & 0.16 & 0.40 \\
\hline C16:0 & 28.56 & 29.02 & 0.35 & 0.14 & 28.72 & 28.83 & 0.33 & 0.68 & 28.79 & 28.79 & 0.34 & 0.99 \\
\hline
\end{tabular}

${ }^{1} \mathrm{C}=$ number of cows; 178 cows with ancestors from 1 genetic line and 55 cows with ancestors within the herd from both genetic lines.

composition (DePeters et al., 1995; Kelsey et al., 2003; Auldist et al., 2004; Soyeurt et al., 2006). In addition, genetic correlations predicted that increased milk yield alters the milk fatty acid profile toward greater milk fatty acid saturation and de novo synthesized fatty acids (Renner and Kosmack, 1974b; Karijord et al., 1982). Selection for milk yield improves feed efficiency by altering homeorhetic control toward increased partitioning of nutrients to the mammary gland and in early lactation toward increased fatty acid mobilization from adipose tissue (Lukes et al., 1989; Kruip et al., 1996; Buckley et al., 2000). Thus, selection for milk yield might decrease milk fatty acid saturation in early lactation, when cows are in negative energy balance. Consistent with our hypothesis, in the first month of lactation, high-line cows had lower proportions of saturated fatty acids ( 61.47 vs. $65.46 \% ; P=0.0009)$ and higher proportions of monounsaturated fatty acids ( $35.07 \mathrm{vs} .31 .16 \%$; $P=0.0006)$ in milk than did average-line cows. Specifically, high-line cows had higher proportions of oleic acid (C18:1; 32.43 vs. $28.48 \% ; P=0.0005)$ and lower proportions of fatty acids that are synthesized de novo in the mammary gland (C6:0, 1.70 vs. $2.17 \%, P=0.0009$; C8:0, 0.82 vs. $1.10 \%, P=0.0004$; $\mathrm{C} 10: 0,1.70$ vs. $2.27 \%$, $P=0.003$; C12:0, 1.72 vs. $2.30 \%, P=0.005$; and C14:0, 6.94 vs. $8.39 \%, P=0.002$ ). However, we did not observe the same significant changes in cows that differed in the average milk PTA of their parents or their own milk PTA (results not shown). Therefore, selection for milk yield had little effect on milk fatty acid profile.

In conclusion, the results clearly demonstrate that selecting cows for increased milk yield decreased milk fat content and, to a smaller extent, milk protein content. However, there was little effect on composition of milk protein and of milk fatty acids. Therefore, continued selection of cows for increased milk yield would not be expected to change composition of milk protein and milk fatty acids if selection is only for a few generations.

\section{ACKNOWLEDGMENTS}

We thank Swiss Valley Farms (Davenport, IA) for analysis of milk samples, D. Olson for use of HPLC equipment, J. W. Young for editorial assistance, D. H. Kelley for coordination of milk sampling, and G. Cooling and C. Sharp for laboratory assistance. The project was supported by the USDA Center for Designing Foods to Improve Nutrition (Ames, IA) and by the Royal Dutch Cattle Syndicate (Arnhem, the Netherlands). Gerd Bobe was supported in part by a scholarship from the National Milk Producers Federation (Arlington, VA).

\section{REFERENCES}

Auldist, M. J., K. A. Johnston, N. J. White, W. P. Fitzsimons, and M. J. Boland. 2004. A comparison of the composition, coagulation characteristics and cheesemaking capacity of milk from Friesian and Jersey dairy cows. J. Dairy Res. 71:51-57.

Bertrand, J. A., P. J. Berger, A. E. Freeman, and D. H. Kelley. 1985. Profitability in daughters of high versus average Holstein sires selected for milk yield of daughters. J. Dairy Sci. 68:2287-2294.

Bobe, G., D. C. Beitz, A. E. Freeman, and G. L. Lindberg. 1998. Separation and quantification of bovine milk proteins by reversedphase high-performance liquid chromatography. J. Agric. Food Chem. 46:458-463.

Bobe, G., D. C. Beitz, A. E. Freeman, and G. L. Lindberg. 1999a. Associations among individual proteins and fatty acids in bovine 
milk as determined by correlations and factor analyses. J. Dairy Res. 66:523-536.

Bobe, G., D. C. Beitz, A. E. Freeman, and G. L. Lindberg. 1999b. Effect of milk protein genotypes on milk protein composition and its genetic parameter estimates. J. Dairy Sci. 82:2797-2804.

Buckley, F., P. Dillon, M. Rath, and R. F. Veerkamp. 2000. The relationship between genetic merit for yield and live weight, condition score, and energy balance of spring calving Holstein Friesian dairy cows on grass based systems of milk production. J. Dairy Sci. 83:1878-1886.

DePeters, E. J., J. F. Medrano, and B. A. Reed. 1995. Fatty acid composition of milk fat from three breeds of dairy cattle. Can. J. Dairy Sci. 75:267-269.

Dunklee, J. S., A. E. Freeman, and D. H. Kelley. 1994. Comparison of Holsteins selected for high and average milk production. 1. Net income and production response to selection for milk. J. Dairy Sci. 77:1890-1896.

Edwards, R. A., J. W. B. King, and I. M. Yousef. 1973. A note on the genetic variation in the fatty acid composition of cow milk. Anim. Prod. 16:307-310.

Gernand, E. 1988. Zur Berücksichtigung qualitativer und quantitative Faktoren der milcheiweißzusammensetzung in der Züchtung. PhD Diss. Forschungszentrum Tierproduktion, Abt. Rinderzucht Clausberg, Dummerstorf-Rostock, Germany.

Jakob, E. 1994. Genetic polymorphism of milk proteins. Bull. Int. Dairy Fed. 298:17-27.

Karijord, Ø., N. Standal, and O. Syrstad. 1982. Sources of variation in composition of milk fat. Z. Tierzücht. Züechtungsbiol. 99:81-93.

Kay, J. K., W. J. Weber, C. E. Moore, D. E. Bauman, L. B. Hansen, H. Chester-Jones, B. A. Crooker, and L. H. Baumgard. 2005. Effects of week of lactation and genetic selection for milk yield on milk fatty acid composition in Holstein cows. J. Dairy Sci. 88:3886-3893.

Kelm, S. C., and A. E. Freeman, and NC-2 Technical Committee. 2000. Direct and correlated responses to selection for milk yield: Results and conclusions of regional project NC-2, "Improvement of dairy cattle through breeding, with emphasis on selection." J. Dairy Sci. 83:2721-2732.

Kelsey, J. A., B. A. Corl, R. J. Collier, and D. E. Bauman. 2003. The effect of breed, parity, and stage of lactation on conjugated linoleic acid (CLA) in milk fat from dairy cows. J. Dairy Sci. 86:2588-2597.

Kroeker, E. M., K. F. Ng-Kwai-Hang, J. F. Hayes, and J. E. Moxley. 1985. Heritabilities of relative percentages of major bovine casein and serum proteins in test-day milk samples. J. Dairy Sci. 68:1346-1348.

Kruip, T. A. M., J. H. J. Vanderwerf, and T. Wensing. 1996. Energy balance in early lactation of high producing dairy cows and its relation to reproduction, health and welfare. Pages 45-57 in Proc. Int. Symp. Util. Local Feed Resour. Dairy Cattle. A. F. Groen and J. V. Bruchem, ed. Wageningen Pers., the Netherlands.
Kuss, A. W., J. Gogol, H. Bartenschlager, and H. Geldermann. 2005. Polymorphic AP-1 binding site in bovine CSN1S1 shows quantitative differences in protein binding associated with milk protein expression. J. Dairy Sci. 88:2246-2252.

Lien, S., L. Gomez-Raya, T. Steine, E. Fimland, and S. Rogne. 1995. Associations between casein haplotypes and milk yield traits. J. Dairy Sci. 78:2047-2056.

Lukes, A. J., M. A. Barnes, and R. E. Pearson. 1989. Response to selection for milk yield and metabolic challenges in primiparous dairy cows. Domest. Anim. Endocrinol. 6:287-298.

McLean, D. M., E. R. B. Graham, R. W. Ponzoni, and H. A. McKenzie. 1984. Effects of milk protein genetic variants on milk yield and composition. J. Dairy Res. 51:531-546.

Ng-Kwai-Hang, K. F., and F. Grosclaude. 2003. Genetic polymorphism of milk proteins. Pages 739-816 in Advanced Dairy Chemistry: Volume 1: Proteins. Parts A and B. P. F. Fox and P. L. H. Sweeney, ed. Kluwer Acad./Plenum Publ., New York, NY.

NRC. 2001. Nutrient Requirements of Dairy Cattle. 7th rev. ed. Natl. Acad. Press, Washington, DC.

Prinzenberg, E.-M., C. Weinmann, H. Brandy, J. Bennewitz, E. Kalm, M. Schwerin, and G. Erhardt. 2003. Polymorphism of the bovine CSN1S1 promoter: Linkage mapping, intragenic haplotypes, and effects on milk production traits. J. Dairy Sci. 86:2696-2705.

Renner, E., and U. Kosmack. 1974a. Genetische Aspekte zur Fettsäurenzusammensetzung des Milchfettes. 2. Fettsäurenmuster der Milch von Nachkommenpopulationen. Züchtungskunde 46:217-226.

Renner, E., and U. Kosmack. 1974b. Genetische Aspekte zur Fettsäurenzusammensetzung des Milchfettes. 3. Genetische Korrelationen zum Fettgehalt und zur Fettleistung. Züchtungskunde 46:257-264.

Renner, E., and U. Kosmack. 1975. Genetische Aspekte zum Eiweißgehalt und zu den Eiweißfraktionen der Milch. II. Eiweißfraktionen. Züchtungskunde 47:441-457.

Rolleri, G. D., B. L. Larson, and R. W. Touchberry. 1956. Protein production in the bovine. Breed and individual variations in the specific protein constituents of milk. J. Dairy Sci. 39:1683-1689.

Sanders, K., J. Bennewitz, N. Reinsch, G. Thaller, E.-M. Prinzenberg, C. Kühn, and E. Kalm. 2006. Characterization of the DGAT1 mutations and the CSN1S1 promoter in the German Angeln dairy cattle population. J. Dairy Sci. 89:3164-3174.

SAS. 2002. SAS User's Guide: Statistics, Version 9.1. SAS Inst. Inc., Cary, NC.

Soyeurt, H., P. Dardenne, A. Gillon, C. Croquet, S. Vanderick, P. Mayeres, C. Bertozzi, and N. Gengler. 2006. Variation in fatty acid contents of milk and milk fat within and across breeds. J. Dairy Sci. 89:4858-4865.

Wilcox, C. J., S. N. Gaunt, and B. R. Farthing. 1971. Genetic interrelationships of milk composition and yield. Agric. Exp. Stn. Bull. No. 155. Inst. Food Agric. Sci., Univ. Florida, Gainesville. 